\title{
EFFECTS OF LEVEL AND DURATION OF PASTURE SILAGE SUPPLEMENTATION ON GAINS AND OVULATION RATES OF EWES
}

P. V. Rattray, K. T. Jagusch, J. F. Shith, G. W. Winn, P. A. Farquhar

Ruakura Animal Research Station, Hamilton

\author{
Abstract
}

Increasing amounts $(0,0.25,0.50,0.75$ and $1.0 \mathrm{~kg} \mathrm{DM} / \mathrm{ewe} /$ day $)$ of chopped $(10 \mathrm{~cm})$ wilted silage $(32.5 \% \mathrm{DM})$ was offered to groups of oestrous-synchronized mixed-age Coopworth ewes $(n=50 /$ group), grazing two restricted levels of autumn pasture (0.8 and $1.6 \mathrm{~kg} \mathrm{DM}$ allowance/ewe/day). Gains over the 48-day trial in. creased linearly with the amount of silage fed from -140 to 68 and from -65 to $105 \mathrm{~g} / \mathrm{ewe} / \mathrm{day}$, respectively, at each allowance. Ovulation rates were measured by laparoscopy at two oestrous cycles. A linear model with logit transformation was used to determine treatment effects on the proportion of multiple ovulations. At both cycles there was a linear effect between multiple ovulations and level of silage intake and thereby sustained gain. Fine-chopped wilted silage proved superior to conventional silage for flushing.

\section{INTRODUCTION}

AFTER recognition of the separate static effect of mating weight per se and the "dynamic" flushing response on lambing performance, ewe liveweight at mating has been emphasized (Coop, 1966).

However, in large areas of the country, poor grazing manage ment and drought often cause such low pasture production, especially in summer and autumn, that it is impossible to support heavy ewe mating weights. Ewes generally, lose weight prior to and during mating, a problem exacerbated by increased stock numbers and/or the higher feed requirements of heavy ewes (Rattray et al., 1978a), Consequently there has been little improvement in the national lambing percentage in the last 15 years (Rattray and Jagusch, 1978). Earlier mating will not overcome the problem, as a lower proportion of ewes will be cycling (Kelly and Knight, 1979).

Recent work at Ruakura (Rattray, Jagusch and Smith, unpublished) has shown that light ewes $(45 \mathrm{~kg}$ ) respond well to flushing, producing similar ovulation rates as flushed heavy ewes $(60 \mathrm{~kg})$. In drought-prone areas where ewe liveweights are low 
and the summer-autumn pasture supply is unreliable, some form of supplement for flushing ewes should be considered. Conservation of spring pasture surpluses as silage is an ideal method of transferring feed forward, and in addition is one of the cheapest supplements available to the pastoral farmer (Marsh, 1978). Initial work with pasture silage as a flushing feed proved disappointing (Rattray et al., 1978c), but subsequent results with wilted silage supplements were more promising (Rattray et al., 1978b).

In 1979 a trial was conducted to 'examine the effect of level and duration of silage supplementation on the responses of ewes grazing restricted amounts of autumn pasture. Two silage diets as sole flushing feeds were also compared in a subsidiary trial.

\section{EXPERIMENTAL}

\section{Matn Trial Desten}

increasing amounts of pasture silage $(0,0.25,0.5,0.75$ and $1.0 \mathrm{~kg} \mathrm{DM} / \mathrm{ewe} /$ day) were fed to groups of 50 mixed-age Coopworth ewes on two levels of submaintenance grazing (pasture allowances of 0.8 and $1.6 \mathrm{~kg} \mathrm{DM} /$ ewe/day).

\section{Silage}

The silage was made from grass-dominant pasture prior to ear emergence in November 1978, cut with a rotary disc mower, wilted for 24 to $30 \mathrm{~h}$, and double chopped into approximately $10 \mathrm{~cm}$ length.

An adjacent area was also flail-cut and ensiled directly.

\section{Management and FeEding}

Mixed-aged Coopworth ewes were oestrous-synchronized with progestagen sponges prior to 8 March (day 1). Feeding started on day 1 and the sponges were removed on day 4. Ovulation rates were measured at the second and third synchronized cycle by laparoscopy at day 28 and day 48, respectively. Rams were joined with the ewes prior to the third cycle so that ovulation and lambing data could be compared.

Full and 24-h fasted liveweights were obtained on days 1, 28, and 48.

Ewes were accustomed to flail-harvested silage for 2 weeks prior to day 1, but during the trial chopped wilted silage was fed.

Each mob was rotationally grazed on relatively short pastures to give nominal submaintenance pasture allowances with five groups being offered 0.8 or $1.6 \mathrm{~kg} \mathrm{DM} /$ ewe/day. 
Pasture Measurements

Pasture measurements (pre-grazing DM/ha, post-grazing $\mathrm{DM} /$ ha, intake or DM disappearance, etc.) and sampling techniques were similar to those reported by Rattray (1977) except that six randomly placed exclosure cages were used per paddock to allow for growth during the grazing period.

\section{SUB-TRIAI}

During the same period groups of 50 ewes were penned on sawdust and fed either flailed or chopped wilted silage ad libitum. Ovulation rates and weight gains were measured as for the main trial.

\section{Sillage Digestibility}

Each week, $100 \mathrm{~kg}$ of chopped wilted silage (wet matter) and $150 \mathrm{~kg}$ of flail-cut silage was frozen and fed later to wethers in metabolism crates to measure apparent digestibility.

\section{RESULTS AND DISCUSSION}

\section{Pasture And Intake Measurements}

No meaningful statistical analyses could be performed on the pasture measurements or group intakes of silage, so the average and ranges are given in Table 1 .

At the lower pasture allowance there was no evidence of substitution of silage for pasture, and hence no difference in utilization/ grazing or pasture intake (DM disappearance). At the higher pasture allowance the pasture-only group appeared to have' a higher per-grazing utilization and pasture intake than the silage-supplemented groups. This group, excepted, total intake increased with increasing amounts of silage eaten, and average pre-grazing and residue yields were approximately 1500 and $500 \mathrm{~kg} \mathrm{DM} / \mathrm{ha}$, respectively, for all groups.

\section{PAsture QUALITY}

The average ( \pm SE mean) proportion of green material in the sward pre-grazing was $84( \pm 3.5) \%$. The proportion of green material in the post-grazing residue for the 1.6 and 0.8 allowances was $67( \pm 7.1)$ and $47( \pm 10.8) \%$, respectively. Ewes showed a marked preference for green material (Rattray, 1978).

The in vitro organic matter digestibility and $\mathrm{N}$ content of the pre-grazing and post-grazing pasture averaged $65( \pm 1.8)$ and $40( \pm 2.8) \%$ and $3.5( \pm 0.12)$ and $2.7( \pm 0.22) \%$, respectively. 


\begin{tabular}{|c|c|c|c|}
\hline Silage & Pasture Utilization & / $D M$ & Total \\
\hline $\begin{array}{l}\text { Offered } \\
(\mathrm{kg} D M / \\
\text { ewe / day) }\end{array}$ & $\begin{array}{l}\text { Allowance } \\
\text { (kg DMlewel } \\
\text { day) }\end{array}$ & $\begin{array}{rr}\text { Disappearance } & \text { Intake } \\
(\mathrm{kg} D M / \text { ewe/ } & (\mathrm{kg} D M / \\
\text { day }) & \text { ewe/day })\end{array}$ & $\begin{array}{l}\text { Intake } \\
(\mathrm{kg} / D M / \\
\text { ewe/day) }\end{array}$ \\
\hline
\end{tabular}

(Allowance 0.8)

\begin{tabular}{|c|c|c|c|c|c|}
\hline tin & $\begin{array}{c}0.81 \\
(0.55-1.46)\end{array}$ & $\begin{array}{c}\mathbf{6 9 . 7} \\
(42.1-85.1)\end{array}$ & $\begin{array}{c}0.64 \\
(0.28-0.92)\end{array}$ & 0.00 & 0.64 \\
\hline 0.25 & $\begin{array}{c}0.87 \\
(0.59-1 \quad .29)\end{array}$ & $\begin{array}{c}64.2 \\
(42.0-83.9)\end{array}$ & $\begin{array}{c}0.51 \\
(0.36-0.68)\end{array}$ & 0.25 & 0.76 \\
\hline 0.50 & $\begin{array}{c}0.87 \\
(0.55-1.14)\end{array}$ & $\begin{array}{c}61.6 \\
(51.3-79.0)\end{array}$ & $\begin{array}{c}0.52 \\
(0.42-0.68)\end{array}$ & 0.50 & 1.02 \\
\hline 0.75 & $\begin{array}{c}0.83 \\
(0.53-1.41)\end{array}$ & $\begin{array}{c}66.5 \\
(49.7-81.8)\end{array}$ & $\begin{array}{c}0.54 \\
(0.37-0.68)\end{array}$ & 0.73 & 1.27 \\
\hline 1.0 & $\begin{array}{c}0.70 \\
(0.44-0.83)\end{array}$ & $\begin{array}{cc}59.5 \\
(49.5-7 & 1.9)\end{array}$ & $\begin{array}{c}0.43 \\
(0.24-0.59)\end{array}$ & 0.98 & 1.41 \\
\hline (Allowance & $1.6)$ & & & & \\
\hline 0 & $\begin{array}{c}1.60 \\
(1.14-2.52)\end{array}$ & $\begin{array}{c}64.9 \\
(26.0-87.9)\end{array}$ & $\begin{array}{c}1.07 \\
(0.41-1.89)\end{array}$ & 0.00 & 1.07 \\
\hline 0.25 & $\begin{array}{c}1.56 \\
(1.10-2.34)\end{array}$ & $\begin{array}{c}45.3 \\
(23.9-66.7)\end{array}$ & $\begin{array}{c}0.72 \\
(0.34-1.11)\end{array}$ & 0.24 & 0.96 \\
\hline 0.50 & $\begin{array}{c}1.48 \\
(1.06-2.64)\end{array}$ & $\begin{array}{c}42.2 \\
(20.1-70.7)\end{array}$ & $\begin{array}{c}0.64 \\
(0.23-1.00)\end{array}$ & 0.48 & 1.12 \\
\hline 0.75 & $\begin{array}{c}1.53 \\
(1.07-2.12)\end{array}$ & $\begin{array}{c}38.0 \\
(18.5-56.9)\end{array}$ & $\begin{array}{c}0.61 \\
(0.23-1.00)\end{array}$ & 0.74 & 1.35 \\
\hline 1.0 & $\begin{array}{c}1.69 \\
(1.12-2.18)\end{array}$ & $\begin{array}{c}39.1 \\
(28.1-62.2)\end{array}$ & $\begin{array}{c}0.71 \\
(0.38-1.06)\end{array}$ & 0.99 & 1.70 \\
\hline
\end{tabular}

TABLE 2: EWE WEIGHT GAINS” (g/day)

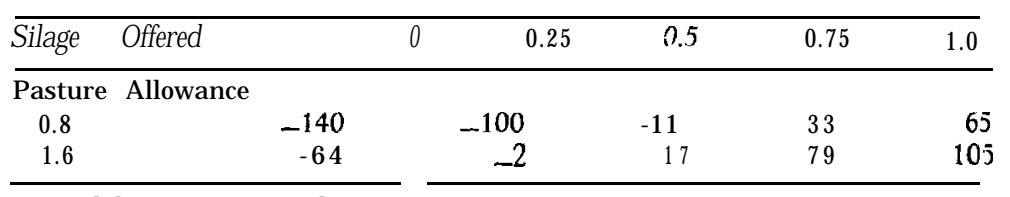

'Fasted basis: 0 to 48 days.

TABLE 3: OVULATION RATES (ova/ewe)

\begin{tabular}{|c|c|c|c|c|c|}
\hline Silage Offered & 0 & 0.25 & 0.5 & 0.75 & 1.0 \\
\hline \multicolumn{6}{|l|}{ Pasture Allowance } \\
\hline 0.8 Laparoscope 1 & 1.20 & 1.30 & 1.46 & 1.38 & 1.64 \\
\hline Laparoscope 2 & 1.20 & 1.20 & 1.50 & 1.58 & 1.70 \\
\hline 16 Laparoscope 1 & 1.48 & 1.16 & 1.52 & 1.62 & 1.66 \\
\hline Laparoscope 2 & 1.36 & 1.36 & 1.36 & 1.70 & 1.74 \\
\hline
\end{tabular}


There were no apparent differences due to pasture allowance or silage fed. These results illustrate that the ewes selected the more digestible components of the sward.

\section{Ewe Weight Changes}

Mean full and fasted liveweights at the start of the experiment were $52.1( \pm 0.68)$ and $48.4( \pm 0.66) \mathrm{kg}$, respectively. At each pasture allowance, weight change was related linearly to the level of silage fed $(P<0.001)$ as follows:

Pasture 0.8: $\mathrm{Y}=192 \mathrm{X}-128$

$$
1.6: Y=192 X-69
$$

where $\quad \mathrm{Y}=$ gain $(\mathrm{g} /$ day $)$ and $\mathrm{X}=$ silage fed $(\mathrm{kg} \mathrm{DM} /$ day $)$.

The quadratic term was not significant, and there were no pasture $x$ silage level interactions. Therefore at any given level of silage fed, the ewes on the higher pasture allowance gained 59 g/day more than those on the lower (or lost 59 g/day less) $(P<0.01)$. Fasted liveweight changes are shown in Table 2.

Daily gain (Y) and total DM intake per day (X) of both groups were represented by the following linear regression (P < 0.001) (Pig. I), Y $=236 \mathrm{X}-268$, and estimated maintenance was at intake of about $1.1 \mathrm{~kg} \mathrm{DM} /$ ewe/day.

\section{Ovulation Responses}

The ovulation rates at the first and second laparoscopies are shown in Table 3.

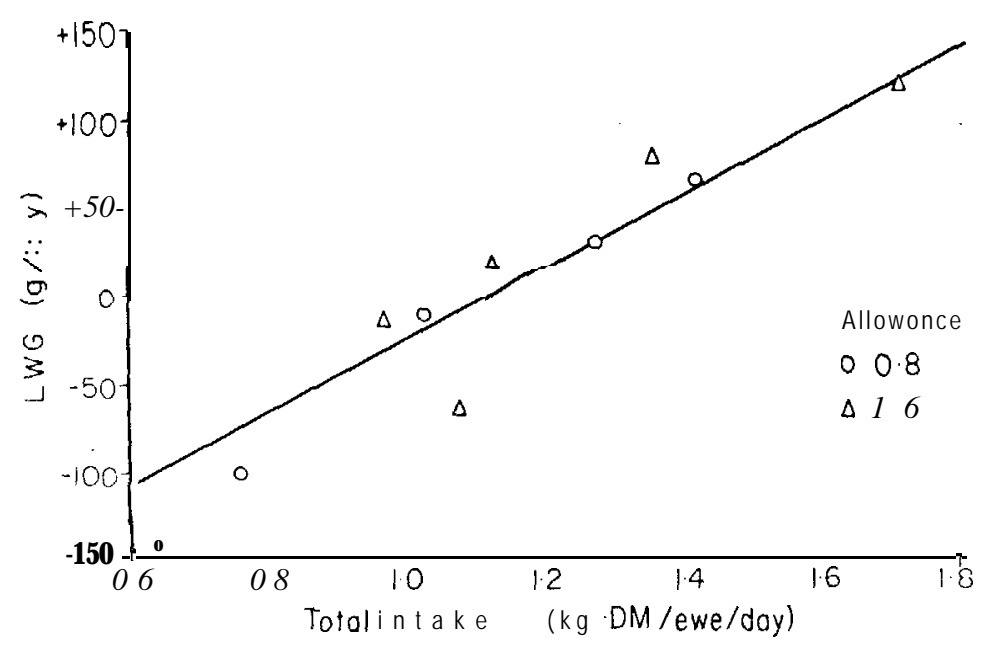

FIG. 1: Relationship between total DM intake and liveweight gain. 


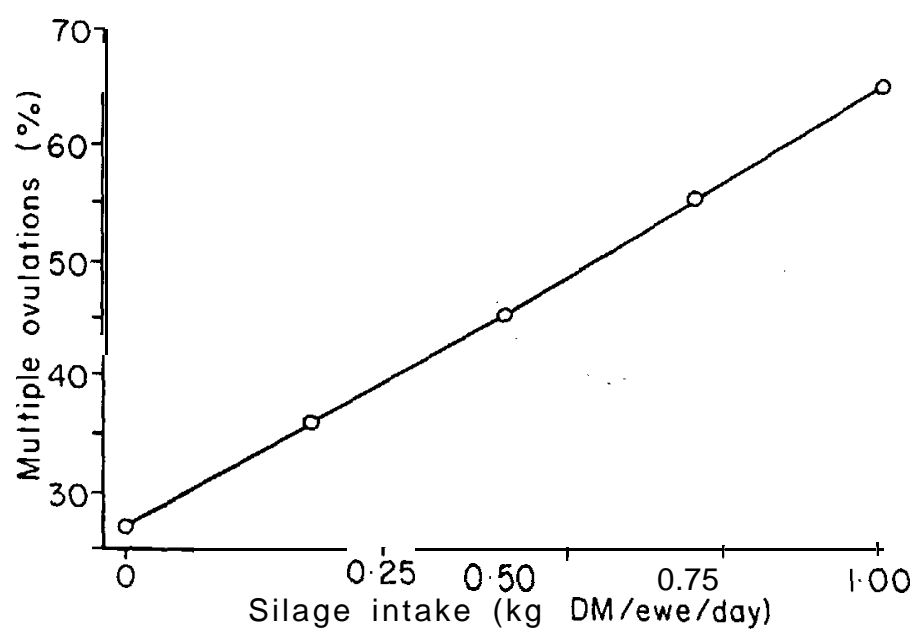

FIG. 2: Relationship between silage intake and percent multiple ovulations.

The proportion of multiple ovulations $(P)$ at both times of measurement was analysed using logit models and the maximum likelihood procedure. The logit transformation is Log. $(P / 1-P)$ as described by Smith et al. (1979), and the actual statistical procedures are given by Nelder and Wedderburn (1972). There were no significant differences between the two pasture allowances, but there was a highly significant $(P<0.001)$ linear effect due to level of silage. The response to silage was the same at both cycles. The overall relationship (Fig. 2) was:

$\log [P /(1-\mathrm{P})]=-0.994+1.62 \times$ silage intake.

No additional improvement of fit was obtained by including terms for allowance and silage when terms for weight gain were already in the model. This suggests that the treatments have little effect on multiple ovulations over and above their effects on weight gain. For the first cycle the effect of daily gain over the first 28 days was significant $(\mathrm{P}<0.05)$. At the second cycle, daily gains over both periods - i.e., 0 to 28 days and from 28 to 48 days - had significant effects $(\mathrm{P}<0.01)$ on the proportion of multiples, but when gain over the whole period ( 0 to 48 days) was included in the model, no improvement of fit was obtained by including terms for gain over these separate periods.

The equations for each cycle were as follows:

Cycle 1: $\log ,[P /(1-\mathrm{P})]=-0.315+5.73 \times \mathrm{kg}$ daily gain $(0-28$ d) 
Cycle 2: $\log ,[P /(1-\mathrm{P})]=-0.202+8.73 \times \mathrm{kg}$ daily gain $(O-48 \mathrm{~d})$.

These relationships had significantly different slopes $(P<0.05)$ and are shown in Fig. 3. This figure, as well as demonstrating the importance of level and direction of weight change on ovulation rate, also demonstrates the effect of duration of weight change. The relationship for cycle 2 in contrast with cycle 1 shows that sustained gain has the more beneficial effect, and sustained loss the more detrimental effect, on multiple ovulations.

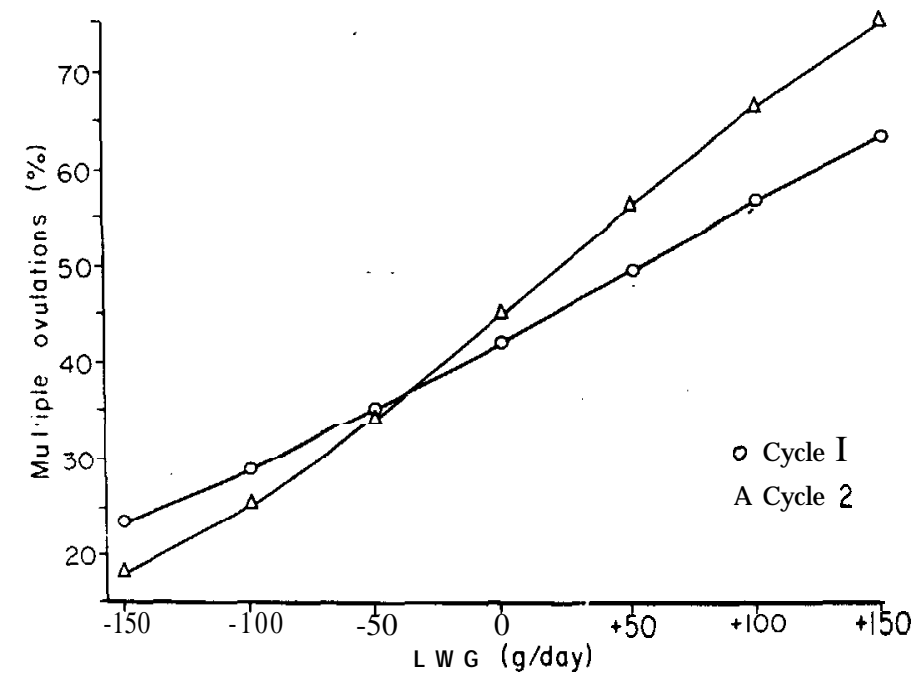

Fig. 3: Relationship between liveweight gain and percent multiple ovulations for two oestrous cycles.

\section{Comparison of Sillages}

The group intakes, weight gains, and ovulation data shown in Table 4 illustrate the superiority of the wilted silage (Marsh, 1978; Rattray, 1977). The toluene dry matter and $\mathrm{N}$ contents of flailcut and chopped wilted silages were 17.3 and $32.5 \%$ and 2.19 and $2.83 \%$, respectively. The DM and $\mathrm{N}$ digestibility coefficients were 72.6 and $75.2 \%$ (SE mean $= \pm 0.25 ; \mathrm{P}<0.01$ ), and 67.4 and $69.5 \%$ (SE mean $= \pm 0.28 ; P<0.01)$, respectively.

\section{CONCLUSION}

This experiment shows the importance of sustained weight gain over the pre-mating period in influencing the proportion of 
TABLE 4: EWE PERFORMANCE ON THE SOLE SILAGE DIETS

\begin{tabular}{|c|c|c|c|c|c|c|}
\hline$\overline{\text { Silage }}$ & $\begin{array}{c}\text { intakg }_{\text {kg }} \text { /ewe } \\
\text { /day) }\end{array}$ & $\begin{array}{l}\text { Weight } \\
\text { Gann } \\
(\text { g/ewe / d a y) }\end{array}$ & $\begin{array}{l}\text { Ovulation } \\
\text { Cycle } 1\end{array}$ & Rate (eggsslewe) & $\begin{array}{l}\text { Multiple } O \\
\text { Cycle } 1\end{array}$ & ations $(\%)$ \\
\hline Flail cut & 0.91 & 32 & 1.33 & 1.51 & 39 & 43 \\
\hline $\begin{array}{l}\text { Fine chop- } \\
\text { wilted }\end{array}$ & 1.65 & 162 & 1.70 & 1.79 & 68 & 69 \\
\hline Significance & & $P<0.01$ & & & $P<0.01$ & $P<0.05$ \\
\hline
\end{tabular}


multiple ovulations obtained from a mob of ewes; High-quality wilted silage is an ideal feedstuff for this purpose on farms where it is possible to transfer feed from the spring surplus to the feed. shortage period of summer and autumn. Wilted chopped silage is superior to flail-cut silage as a flushing feed, because of the higher intake and gains obtained.

\section{ACKNOWLEDGEMENTS}

To Mrs M. E. Petch for records; 'L. T. McGowan for assistance with laparoscopy; to staff of the Nutrition Centre for analyses and digestibility measurements; and to the Sheep Nutrition staff for field work.

\section{REFERENCES}

Coop, 1. E., 1966. W orld R eview of Anim. Prod, 4: 69-78.

Kelly, R. W.; Knight, T. W., 1979. Proc. Ruakura Fmrs' Conf.: 19-26.

Marsh, R., 1978. Proc. Agron. Soc. N.Z., 8: 135-40.

Nelder, J. A.; Wedderburn, R. W. N., 1972. J. R. Statist. Soc., A. 13.5: 370.

Rattray, P. V., 1977. N.Z. Il exp. Agric., 5: 345-8.

1978. Proc. Agron. Soc. N:Z., 8: 103-X.

Rattray, P. V.; Jagusch, K. T., 1978. Proc. 28th Lincoln Coll. Fmrs' Conf.: 154-71.

Rattray, P. V.; Jagusch, K. T.; Clarke, I. N.; MacLean, K. S., 1978a. Proc. Ruakura Fmrs' Conf., Aglink, 30 RFC: 1/4000/8/78: FPP 164.

Rattray, P. V.; Jagusch, K. T.; Smith, J. F., 1987b. Proc, Ruakura Fmrs' Conf., Aglink, 30 RFC: 1/4000/8/78: FPP 155

Rattray, P. V.; Jagusch, K. T.; Smith, J. F.; Tervit, H. R., 1978c. Proc. N.Z. Soc. Anim. Prod., 38: 101-4

Smith, J.'F.; Rattray, P. V.; Jagusch, K. T.; Cox, N. R.; Tervit, H. R., 1979. Proc. N.Z. Soc. Anim. Prod., 39: 50-5. 